Open Access

\title{
Factors influencing access to finance by SMEs in Mozambique: case of SMEs in Maputo central business district
}

\author{
Hezron Mogaka Osano ${ }^{1 *}$ and Hilario Languitone ${ }^{2}$
}

\author{
*Correspondence: hezron.osano@ \\ gmail.com \\ ${ }^{1}$ Africa Nazarene University, P.O. Box \\ 53067 - 00200 Nairobi, Kenya \\ Full list of author information is \\ available at the end of the article
}

\begin{abstract}
SMEs play an important role in the economic development of Mozambique. Access to finance is important for the growth of SMEs. Thus, the purpose of the study was to establish the factors that influence access to finance by SMEs. The factors that were addressed included structure of financial sector, awareness of funding opportunities, collateral requirements, and small business support services. The target population was 2725 which comprised of 2075 staff of three Banks, namely BIM Bank, BCI Bank, and Standard Bank and 650 SMEs in Maputo Central Business District. The research focused on a sample size of 242 SMEs and 324 staff of the named Banks. Descriptive and inferential research design was used. Structured questionnaires were used to collect the primary data. The findings from the study were that there is a relationship between the structure of the financial sector and access to finance by SMEs; there is a relationship between awareness of funding and access to finance by SMEs; there is a relationship between collateral requirements and access to finance by SMEs; and there is a relationship between small business support and access to finance by SMEs. The study findings are significant since they would enable the government to come up with appropriate regulation, funding programs, and schemes toward improvement of access to finance by SMEs. This study concludes that small business support services should be provided to SMEs to improve access to finance and that there is a need for more funding programs and financial schemes to assist SMEs. It is further concluded that since information is concerned with funding opportunities by SMEs, then relevant information should be available and known to all players in the financial market.

Keywords: Collateral requirements, Small business support services, Structure of financial sector, Awareness of funding opportunities, Access to finance
\end{abstract}

\section{Background}

The accessibility of finance by SMEs has stirred attention of academicians and policy makers worldwide for many decades. Discussion on the problem of access to finance by SMEs in Mozambique has taken place in form of seminars and several debates for the purpose of improving the finance line for SMEs and to formally integrate their contributions in the economy (MIC, 2007). This is because finance is a significant element for determining the growth and survival of SMEs (ACCA, 2009). Access to finance allows small businesses to undertake productive investments and contribute to the development of the national economy and alleviation of poverty in most of Sub-

\section{Springer}


Saharan African countries (Beck and Demirguc-Kunt, 2006). External finance for small and medium enterprises is essential for boosting start-up businesses. In addition, without external finance, small and medium enterprises will probably not be able to compete in an international market, to expand the businesses and strike linkages of business with the large firms. Further, access to finance is the most serious barrier to expansion of businesses and start-ups which have been mentioned by existing SMEs and potential operators (Olomi and Urassa, 2008).

In the context of Mozambique, the small enterprises are those with less than ten employees and medium enterprise with employees between 11 and 50. The large enterprises are those which have more than 50 employees. It is observed that $98.6 \%$ of Mozambican firms are composed of SMEs. They provide more employment, diversification, and stimulus for innovations, mobilize social and economic resources, and provide a greater level of competition. In this regard, the government needs to employ suitable strategies in order to minimize the scarcity of bank financing for SMEs in the country and drive the national economic development (MIC, 2007). This pattern is repeated in Brazil, where SMEs account for $99 \%$ of formal companies (IBGE, 2007), and in the UK where $99.8 \%$ of the jobs are in SMEs (FSB, 2012).

Only $5 \%$ of the SMEs are financed through banking institutions meaning they use other financing lines for both investment and working capital (MIC, 2007). Practically many of the SMEs finance their projects through their own funds, family funds, and friends' funds due to a number of difficulties in accessing bank financing (MIC 2007). Non-banking institutions, non-governmental development banks, also finance SMEs. The non-banking institutions include PODE (Development of Enterprises' Projects) that provide long-term financing in a period of 2.5 to 7 years (MIC, 2007). In addition, some other non-banking institutions focus in funding small agriculture and some other sectors. Those institutions include GAPI (Society for Management in Financing and Promoting the SMEs), FFPI (Small Industries Funding Program) which provide funds for small industries, and FARE (Funds for Aiding and Rehabilitation of the Economy) (MPD, 2007). There are a number of challenges SMEs face that prevent them from conducting their businesses effectively and efficiently. The cost of finance products in the country is high (25-30\%). Even if the financial market is stabilized, banks face issues of high overhead costs and this influences the price of finance products (MIE, 2010). The financial institutions have highlighted several constraints encountered by SMEs which limit the provision of finance products to SMEs. The constraints faced by SMEs are associated with the lack of clear financial plans, the accounting documentation, higher rate of interest, and the lack of collateral requirements (MIC, 2007). There remain in the country important policy challenges on the lending side.

As in other countries in the world, Mozambique focuses on both demand and supply side (Central Bank of Mozambique, 2013). The demand side encourages the commercial banks to provide finance to the small businesses through guarantees and provide more financial assistance through the affordable cost of capital, micro-finance, and innovation fund. On the supply side, this focus is in diminishing the asymmetries of information between the two players (lenders and borrowers). The relevant information between lenders and borrowers should be provided to improve the situation (Central Bank of Mozambique, 2013). Yet, small and medium enterprises still face a number of constraints in accessing bank financing attributed to lack of collateral requirements, 
structure of the financial sector, awareness of funding opportunities, and small business support services (Manasseh, 2004).

Indeed, financial constraints in Mozambique weigh down the SMEs and many of them collapse during the first year of start-up due to lack of financial resources to run the business. SMEs contribute over $20 \%$ of the country's revenue (MPD, 2007). Therefore, an improvement of the financial systems is necessary as is the need to adopt suitable mechanisms in order to assist small businesses financially.

Therefore, this study investigated the factors influencing access to finance by SMEs in Mozambique in order to set some light on how the problem of access to finance would be addressed to reduce the number of SMEs collapsing.

\section{Literature review}

This section presents both the theoretical and empirical review of the related literature on the subject under study.

\section{Theoretical review}

Information asymmetry theory Information asymmetry theory postulates that when two parties are making decisions or transactions, there exists a situation where when one party has more or better information than the other. Thus, information asymmetry may cause an imbalance of power between the parties.

In this context, for example, the borrowers are more likely to get more information than the lenders. Information related with the risk associated with the investments is likely to be available to the borrowers. Matthews and Thompson (2008) observed that this may lead to the problems of moral hazard, where a party will take risks because they assume final cost of that risk, as well as adverse selection, where there are adverse results because parties have different/imperfect information; therefore, the problems may cause inefficiency related to the flow or transfer of funds from the lenders (surplus) to the borrowers.

Furthermore, for overcoming these issues, the financial intermediaries use three major ways such as providing the commitment for long-term relationship with the clients. The second way is through the sharing of the information. Lastly is through the delegation and monitoring of the credit applicants. When the customers borrow money directly from banks, the banks should consider the need for relevant information to be addressed and so as to redress the asymmetry of the information (Matthews and Thompson, 2008).

It is argued that the acuteness of information asymmetries between bankers and entrepreneurs is the main stumbling block to SME financing in Sub-Saharan Africa. However, the gap between banks and SMEs can be narrowed by developing financial systems that are more adapted to local contexts. In addition, avenues should be explored for sharing of risks and reduction of perceived risks by banks by promoting sustainable guarantee funds to facilitate better access to financing by SMEs (Leffileur, 2009).

\section{Empirical review}

Many factors have been considered for the purpose of explaining the scarcity of bank financing by SMEs. Anzoategui and Rocha (2010) have suggested that competition in financial sector is more crucial. The lack of it can actually raise the price of financial 
products and influence directly the growth of small firms and the younger firms in the world. They have also added that the low level of competition in the financial sector can probably affect the stability of the banking industry.

In the context of UK, it is believed that access to finance by SMEs is closely affected by the differences in commercial banks or the practices and the policies of the supply side of finance. It is argued that most of the commercial banks in UK differ in terms of the relationship between those lending institutions and the entrepreneur (BBA, 2002; Watanabe, 2005). The World Bank (2003) identified a number of factors that constitute constraints by SMEs to access finance. These factors include distortions of financial sectors, lack of know-how on the banking part, information asymmetry (access to business information), and the high risk in lending to small businesses.

The study of Beck (2007) identified that the weaknesses in financial and legal systems present, in the developing countries, an obstacle in accessing finance products. When Beck analyzed 70 developing countries, he concluded that the local government has actually the entire responsibility to build institutions. Market activities should be undertaken in friendly manner in order to provide a proper regulatory framework to reduce financial constraints by SMEs. Some studies (Bigsten, 2003; Yitayal, 2004), with the main focus on the developing countries, observed that the lack of collateral requirements, high risks, information asymmetries, small credit transactions particularly of rural households, and the distance between lender-borrowers as the main causes for credit variation among the different and existent sources of credit. In addition, the same researchers state that the policy and the type of financial institution in one or in other way determine access to finance.

It has been remarked that interest rates charged by banks in Sub-Saharan Africa create disincentives for most borrowers to acquire funds to invest in their businesses on one hand. On the other hand, the interest rates charged by banks discourage most small businesses from applying for bank financing (Diagne and Zeller, 2002; Foltz, 2004). Fatoki and Smit (2011) in South Africa grouped the major factors that influence the low access to finance by SMEs in two ways; internal and external. The internal factors include the business information, collateral, networking, and managerial competences. External factors constitute the legal environment, crime and corruption, ethical perceptions, and macro-economy.

Olomi and Urassa (2008), in the study based in Tanzania, identified three major groups of constraints of access to finance by SMEs. The first group of factors included the capacity (low level of knowledge and skills), under-developed culture of business, non-separation of the business between personal issues and family, credit history of SMEs, and lack of knowledge of available finance services. The second group of factors included the number of competent personnel and lack of experience of SMEs. The third group of factors is related to the regulation of the environment where transactions occur between lenders and borrowers, lack of system identification, and credit reference bureaus.

From the study of Brownbridge (2002), it is noted that loan term places an important element when it comes to lending issues. The loan term affects the revenue of lending institutions (banks), the repayment schedule of credit applicants, the financial cost of customers, and also the sustainability of the use of the finance products. It is further stated that in most cases the loan period and the size present obstacles for accessing 
bank financing and the interest rate affects access to finance in some few cases. Several studies (Kaufmann and Wilhelm, 2006; World Bank, 2003; USAID, 2005; USAID, 2007) found that the major problems concerning access to finance for small businesses in Mozambique are basically related with the high interest rate charged on financial products and the inefficient banking services, than would be justified by economic reasons. Thus, interest rates in Mozambique are at higher levels compared to other SubSaharan African countries. Furthermore, the differences in interest rates vary based on the currencies. The loans made on the domestic currency Metical (MZN) carry higher interest rates than those made in US dollar (USAID, 2007).

The commercial banks of Mozambique impose excessively high interest rates and fees in various services, such as transfer of funds, account statements, banking guarantees, and letters of credit. Many SMEs do not attempt to acquire finance from commercial banks due to the high interest rates charged (Kaufmann and Wilhelm, 2006). Consequently, most of the SMEs use their own capital, funding from family and friends for working capital, and investment capital as well. The World Bank (2003) shows that $90 \%$ of working capital and $64.9 \%$ of new investments were financed by SMEs' own capital, compared to $6.9 \%$ working capital and $8.2 \%$ of new investments which were financed by the banking institutions indicating low access to finance by SMEs in Mozambique. We consider a number of factors that affect access to finance by SMEs in Mozambique.

Collateral requirements Collateral refers to the extent to which assets are committed by borrowers to a lender as security for debt payment (Gitman, 2003). The security assets should be used to recover the principal in case of default. SMEs in particular provide security in form of properties (houses, the businesses, the car, and anything that could actually bring back the principal) in case of default on loans (Garrett, 2009). Security for loans must actually be capable of being sold under the normal conditions of the market, at a fair market value and also with reasonable promptness. However, in most banks, in order to finance SMEs and to accept loan proposals, the collateral must be $100 \%$ or more, equal to the amount of credit extension or finance product (Mullei and Bokea, 2000).

Moral hazard issues can be reduced by collateral requirements by increasing and adding a potential cost to borrowers when those are not making their best effort. Sometimes the borrowers extract the funds provided by the lenders for their own personal and private use. Therefore, the collateral requirements when in place can reduce negative consequences that can rise due to an improper utilization of the funds by SMEs. It is evident that most SMEs are denied and discriminated by the lenders in providing financing. This is because of high risk and for not having adequate resources to provide as collateral (Kihimbo et al. 2012).

Small business support services Governments all over the world have designed a number of support services for SMEs which include the policy initiatives and support programs for the purpose of creating and developing the SME sector. Support programs are designed to assist SMEs in order to link them to the larger developmental vision of the nation with the main focus being poverty reduction and growth of small firms (Charbonneau and Menon, 2013). 
A number of initiatives for SME support are in place in many countries which include Brazil, Argentina, Chile, Uruguay, and Mexico. In the European Union and other countries, such initiatives are covered by the specific acts of SMEs: in India by Micro and SME Development Act, in Kenya by Micro and Small Enterprises Act, in Malaysia by SME Master plan, in Tanzania by the SME Development Policy, and in the USA by the Small Business Act (Charbonneau and Menon, 2013). The government of Kenya has put in place the Micro and Small Enterprises Act as initiative aimed at encouraging all Kenyans in establishing SMEs by creating an enabling environment for small businesses to thrive and enhancing access to funding (Rambo, 2013).

For their sustenance, SMEs need to use ICT in order to become more competitive and to provide opportunities to participate in the global value chains (Charbonneau and Menon, 2013). Small business support services are provided by national agencies, both private and public. Indeed, most SMEs are not aware of funding programs and that most SMEs face difficulty in accessing funds to invest in their projects.

It is pointed out that in South Africa there are a number of financial schemes and funding programs that support the SMEs' access to finance. In this context, these schemes and funding programs are promoted by both the private and the public agencies. Despite availability of those funding programs in South Africa, there was a low awareness of funding programs especially government support schemes (DTI, 2010). In Mozambique, a number of difficulties in supporting SMEs have been discussed. In resolving these difficulties, some initiatives have been developed for the purpose of dealing with the issue of access to finance by SMEs. One of such initiative was the conference of "Know and Use Financing SMEs" organized by IPEME, entrepreneurs, banks, and insurers to discuss finance constraints by SMEs (MIC, 2007). The banking schemes and insurance institutions are the bridge for linking these funds to SMEs and the implementation of funding. Therefore, there is need for mutual understanding of the obstacles and difficulties in accessing bank financing. It is pointed out that SMEs generate, in total, more jobs than larger companies and are fundamental to the competitiveness of the country as well as in stimulating innovation (IPEME, 2013).

The government plays a crucial role by leveraging small business owners to implement additional funding mechanisms for SMEs by encouraging, promoting and supporting private initiatives (MIC, 2007). In addition, the Institute for the Promotion of Small and Medium Enterprises has several programs for creating and strengthening businesses, providing integrated assistance in management and business development (training and preparation of business plans). However, these programs seem not to be enough as the rate of rejection is higher particularly for bank sponsored schemes in financing SMEs (IPEME, 2013).

Structure of financial sector Competition in the financial sector is more important particularly for the cost of services and products in the banking industry. Furthermore, the level of competition in the financial sector provides and determines the price of financial products and the level of access to finance by small businesses (Thorsten and Maksimovic, 2003). The direct competition in the banking industry may impact on the growth of new firms and younger firms. If there is low competition, this will undermine the overall stability of the banking industry. In addition, the products and services 
might be expensive and there will be less growth of new firms (Anzoategui and Rocha, 2010).

The banking system regulatory structure should have a greater implication between concentration of the market and access to finance. It is important to note that when there is a high regulatory regime, then entry barriers may increase. In most cases, the competitiveness of the banking system will not rely on the actual market structure but will rely on the regulatory regime of the country (Black and Philip, 2002). There is no clear relation between regulatory restriction, interference of the government on the process of intermediation and banking system's competitiveness and SMEs' access to finance. However, the regulatory restrictions may reduce the efficiency and competitiveness in the banking system and further block banks from using their information advantages (Scott and William, 2001).

The ownership structure of banks may influence the relation between access to finance, market power, and costs of external financing. Local domestic banks are more likely to pursue more information, better enforcement mechanisms than the foreign owned banks, and foreign banks may be willing to lend to opaque borrowers (Cetorelli and Michele, 2001).

Awareness of funding opportunities The flow of information in the financial market is crucial for both SMEs and financial providers (Falkena et al. 2001). In order for SMEs to identify potential supplier of financial services, they require enough information. The financial institutions require information to enable them to evaluate the potential risks associated with the SMEs that apply for bank financing and also to access the location where the same SMEs will be operating and its market segments (Othieno, 2010). Information is concerned with awareness of funding opportunities by SMEs. In addition, information asymmetry is that relevant information is not available and known to all players in the financial market (Agostino, 2008). Information asymmetries are actually concerned with the two players in the financial market. In this case, the borrowers know more about their business cases and the bankers may not know more about it on one hand. On the other hand, it entails the lack of timely, accurate, quality, quantity, and complete information regarding the ability of the applicants to repay back the loan and to access financial products from the banking institutions (Bazibu, 2005).

A study by Agostino (2008), conducted on agricultural sector, pointed out that the failure of the current African market is because of the number of the current agricultural credit problems. These problems are associated with the imperfection of the information in the risk presences. The failures of the market mostly occur due to the fact that it is costly to screen credit applicants. The imperfections of the information affect almost all small holder farmers who are in most cases African women.

Access to finance For SMEs, there are two external financing that are mostly important for financing the businesses. The first is the equity financing which is provided in form of venture capital and available for new small businesses (Deakins, 2008). However, due to lack of equity financing, the small businesses go after debt financing that is mostly provided by the banks and non-banking institutions. Indeed, access of debt financing is very limited especially for SMEs due to the requirements for the provision of debt (Deakins, 2008). 
Equity financing The equity financing method refers to the extent to which the company issues a certain portion of shares of its stock and in return receives money. Depending on how the SMEs raise the equity capital, the debtors have to relinquish a certain portion of the business often 25 to $75 \%$ of the business (Covas and Haan, 2006). Gomes et al. (2006) pointed out that equity financing is a method for raising funds for any investments. In this context, equities are issued in the form of common stocks which gives a claim to share in the net incomes after expenses and taxes. Equity holders are paid periodically in form of dividends and can be considered as a long-term security as there is no maturity date. In South Africa, as in other countries in the world, there is a misperception that a broad supply of debt financing to SMEs will overcome most development problems that SMEs face. In practice, SMEs without a proven track record experience debt financing's shortage (Mahembe, 2011).

The Cruickshank Commission of UK highlighted that intervention of the government in the past meant to stimulate the provision of debt finances had been misdirected. However, intervention of public policy has to be reoriented away from debt financing, in order to put in place and emphasize initiatives that help to facilitate the provision of equity financing to small businesses. The national government should then support the expansion and establishment of venture capital funds. According to Cruickshank Commission, there are a number of results of the market failure in the provision of SMEs' equity financing. These include insufficient SME risk capital being available to SME sector, mainly to high growth potential SMEs and illiquid equity market for small firm sectors (Falkena et al., 2001).

Debt financing Debt financing refers to the case where companies get finance products in a form of loan from lending institutions and give their promise to repay back at a given period of time and interest rate (Cooper and Ejarque, 2003). Furthermore, debt financing is the most common instrument used in the financial market for obtaining funds for investments and to finance new businesses including SMEs. This involves an agreement between the lenders and the borrowers, concerning the fixed interest rate to be paid for the loan in a given period of time. The maturity date of a debt of less than 1 year is considered as short-term debt and more than a year is considered as the long-term debt (Mahembe, 2011). Debt financing includes, therefore, the secured loans which involve the collateral requirements for securing bank financing. When the SMEs default on the loan commitments, banks usually rely on collateral to recover the money invested in a particular business (Falkena et al., 2001).

In the case of unsecured loans, the lender provides loans taking into account the borrower's reputation. For that transaction to take place, a strong relationship between the borrowers and the banks is needed. Loans of this kind are usually short term and the rate of interest is often high (Cole, 2003). Most of the lenders are more unlikely to provide unsecured loans to the small businesses unless there was a lot of business that were made in the past between the borrower and lender, otherwise the lender will still insist that the borrower provide collateral for the loans. The insistence of the lenders on collateral relies on the borrower's present financial and economic conditions. The loans are actually subjected to the repayment period which include short time (less than 1 year or between 6 and 18 months), the intermediary term (the repayment between 3 years), and the long term (paid back in 5 years) (Falkena et al., 2001). 
Bank financing is important for the growth of small firms. Young businesses and any other enterprises in the world including SMEs depend mostly on bank financing to boost the business and to carry out new investments and projects. In addition, funding of investment includes equity and other forms of debt. The various studies on the area of access to finance have pointed out the challenges that SMEs face, in Mozambique in particular and in the world in general, which include the lack of collateral, cost of capital, business plan, and number of lending institutions (USAID, 2007; Anzoategui and Rocha, 2010; Brownbridge, 2002; Fatoki and Smit, 2011; Olomi and Urassa. 2008; Beck, 2007).

\section{Conceptual framework of the study}

The conceptual framework of this study shows the focus on the factors influencing access to finance by small and medium enterprises. The variables in the conceptual framework are tested as hypotheses to establish the relationships between variables.

The independent variables of this study include the collateral requirements, structure of financial sector, small business support services, and awareness of funding opportunities and the dependent variable is the access to finance by SMEs. The measures or indicators for access to finance include the amount of financing provided to SMEs as a total funding, increase in number of SMEs accessing bank loans, and the percentage of bank financing as total of SMEs' funding. Figure 1 shows the conceptual framework showing the relationship among variables.

\section{Methods}

Descriptive and inferential research design was used. In this study, both simple random sampling and stratified sampling were used. Simple random sampling was used in order to select the SMEs from the total population. The stratified sampling was used to classify the respondents into categories that included the relevant management and the staff dealing with SMEs from BIM Bank, BCI Bank, and Standard Bank.

The target population of the study was 2725 which comprised 2075 of bank staff of BIM Bank, BCI Bank, and Standard Bank and 650 small and medium enterprises in Maputo Central Business District. The SMEs were those licensed and which operate under the legal framework of doing business in Mozambique. The population of the

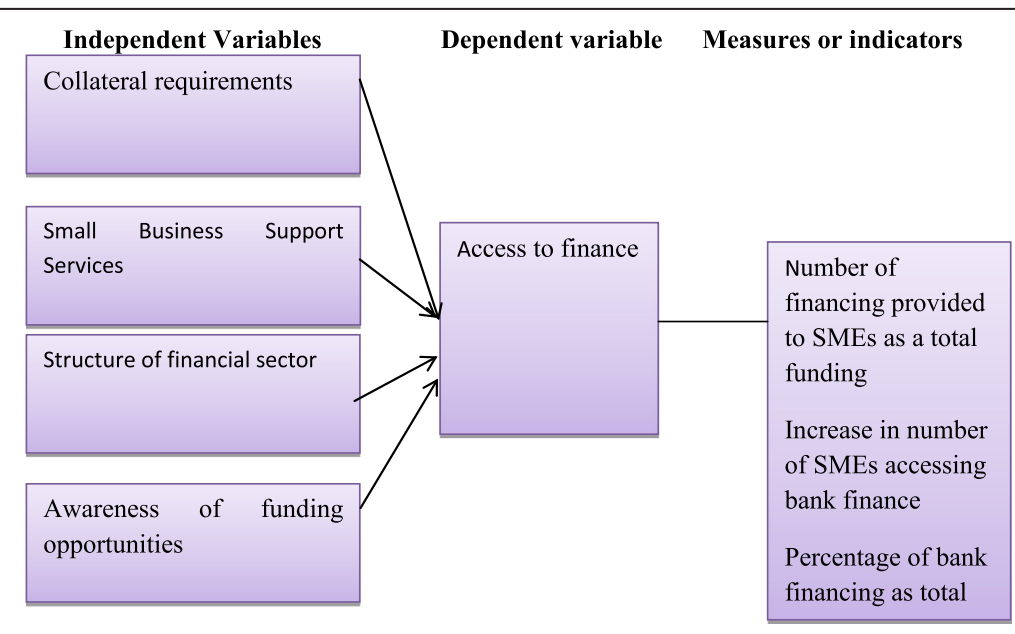

Fig. 1 Conceptual framework 
banks included the staff of BIM Bank, BCI Bank, and Standard Bank which were accessed in their respective Banks Head Offices (INE, 2012).

To determine the sample, the following formula provided by Easterby-Smith et al. (1999) was used by the researcher.

$$
\mathrm{SS}=Z^{2} p q\left(\frac{N}{E^{2}(N-1)+Z^{2} p q}\right)
$$

\section{Description}

- $\mathrm{SS}=$ required sample size;

- $z=z$ value at $95 \%$ confidence level (1.96);

- $p$ the population in the target population estimated to have characteristics being measured (50\%);

- $q=100-p=50 \%$;

- $N=$ total population;

- $E=$ margin error.

Assume $50 \%$ of the population being measured. A sample size of 242 SMEs was computed from a population of 650 SMEs and 324 employees from a population of 2075 employees from three banks split (as in Table 1) were taken.

From the data collected, out of the 242 questionnaires administered to SMEs owners, 123 were filled and returned; and out of the 324 questionnaires that were administered to employees working in the banks, 222 were filled and returned. This represented a response rate of 50.8 and $68.5 \%$, respectively. This corroborates Bailey's (2000) assertion that a response rate greater than $50 \%$ is adequate. This implies that based on this assertion the response rate in this case of 50.8 and $68.5 \%$ is good. Data obtained from research instrument was analyzed using the Statistical Package for Social Science (SPSS). Data were also arranged in a meaningful form, into tables of frequencies, percentages, and charts.

\section{Results}

This section presents results and findings from the study. The first section deals with the background information of the respondents; while the other five sections present findings of the analysis, based on the objectives of the study where both descriptive and inferential statistics have been employed.

Table 1 Sample size for banks

\begin{tabular}{llll}
\hline Banks & Employee population & Sample size & Percentage (\%) sample \\
\hline BIM Bank & 805 & 126 & 39 \\
BCl Bank & 860 & 133 & 41 \\
Standard Bank & 410 & 65 & 20 \\
Total respondents & 2075 & 324 & 100 \\
\hline
\end{tabular}




\section{Validity and reliability results Validity results}

Validity refers to the degree to which the measures of the instruments measure what it is supposed to measure (Joppe 2000; Mugenda, 2008). Face validity of a measuring instrument was established by pre-testing questionnaires on four SMEs. The research assessed the clarity and ease of use of the research instruments and any sensitive, biased items were identified and modified.

Content validity of this study was determined by first discussing the items in the instrument with three experts who indicated against items (with a rating scale of 1-4) in the questionnaire whether it measured what it was meant to measure or not in relation to the research objectives. Content validity index of 0.802 was computed. Mugenda and Mugenda (2003) recommend a content validity index of above 0.5 , indicating that the validity of the instrument was acceptable.

\section{Reliability results}

Reliability of research instruments indicates the degree to which the research is without bias therefore ensured consistent measurement across time and the several items within instrument (Kothari, 2004). The study used the Cronbach's alpha coefficient to determine the internal consistency of the scale that was used to measure the reliability of the variables of the study. In this regard, a Cronbach's alpha of 0.6 is considered satisfactory and 0.7 to 0.8 good (Cooper and Schindler 2008; Mugenda and Mugenda, 2003; Sekaran and Bougie, 2013). The alpha coefficients were all greater than 0.7, indicating an acceptable reliability of the instruments. The instrument therefore was appropriate for the study (see Table 2).

\section{Pearson's correlation matrix}

The study conducted a correlation analysis of the variables of the study which included collateral requirements, awareness of funding opportunities, structure of financial sector, and small business support services and access to finance. To establish the relationship between the variables, the study used Karl Pearson's coefficient of correlation (see Table 3). It was found that there was a positive correlation between collateral requirement and small business support services $(r=0.331)$. It was also found that there was a positive correlation between collateral requirement and structure of financial sector $(r=0.564$, sig. 0.1, two-tailed). However, there was no significant correlation between all the independent variables and access to finance.

\section{Regression analysis}

Multiple regression analysis was used to establish the relationship between the variables of the study. In doing so, the regression model below was used: $y=\beta 0+\beta 1 \times 1+\beta 2 \times 2$

Table 2 Reliability results

\begin{tabular}{lll}
\hline Variable & Cronbach's alpha & Number of items \\
\hline 1. Collateral requirement & 0.7319 & 3 \\
2. Small business support services & 0.8462 & 3 \\
3. Awareness of funding opportunities & 0.7453 & 3 \\
4. Structure of financial sector & 0.7558 & 3 \\
\hline
\end{tabular}


$+\beta 3 \times 3+\beta 4 x 4+\varepsilon$. where $y=$ dependent variable (access to finance); $\beta 1-\beta 4=$ model parameters or coefficients; $x_{1}-x_{5}=$ independent variables namely structure of financial sector, awareness of funding opportunities, collateral requirements, and small business support services; and $\varepsilon=$ error terms.

Table 4 shows a model summary and indicates the adjusted $R$ square used as test for model fitness. The $F$-test was carried out to test the significance of the regression model in predicting the dependent variable (access to finance). From the results, it was found that the four independent variables moderately predict access to finance in SMEs (adjusted $R$ squared $=0.703$ ). That means the model explains $70.3 \%$ the variance in the access to finance; $29.7 \%$ of variations are brought about by factors not captured in the objectives. Therefore, further research should be conducted to investigate the other factors $(29.7 \%)$ that affect access to finance in SMEs. The regression equation appears to be very useful for making predictions since the value of $R^{2}$ is close to 1 . Table 5 indicates the ANOVA ( $F$-test results for the regression model).

The null hypothesis was rejected because the linear regression $F$-test results $(F=4.244$; and $446 \mathrm{df})$ are significant at $p<0.05$. Therefore, the null hypothesis $\left(\mathrm{H}_{\mathrm{o}}\right)$ was rejected and concluded that the regression model linearly explains the access to finance. Therefore, the study accepted alternative hypothesis:

$\mathrm{H}_{\mathrm{a} 1}$ : There is a relationship between collateral requirement and access to finance;

$\mathrm{H}_{\mathrm{a} 2}$ : There is a relationship between small business support services and access to finance;

$\mathrm{H}_{\mathrm{a} 3}$ : There is a relationship between awareness of funding opportunities and the access to finance; and

$\mathrm{H}_{\mathrm{a} 4}$ : There is a relationship between structure of financial sector and the access to finance

The study conducted a multiple regression analysis so as to determine the regression coefficients $(\beta)$ which shows that all the independent variables of collateral requirement, awareness of funding opportunities, structure of financial sector, and

Table 3 Pearson correlation coefficient matrix

\begin{tabular}{|c|c|c|c|c|c|}
\hline & $\begin{array}{l}\text { Collateral } \\
\text { requirement }\end{array}$ & $\begin{array}{l}\text { Small business } \\
\text { support services }\end{array}$ & $\begin{array}{l}\text { Awareness of } \\
\text { funding } \\
\text { opportunities }\end{array}$ & $\begin{array}{l}\text { Structure of } \\
\text { financial sector }\end{array}$ & $\begin{array}{l}\text { Access to } \\
\text { finance }\end{array}$ \\
\hline $\begin{array}{l}\text { Collateral } \\
\text { requirement }\end{array}$ & 1 & 0.331 & 0.054 & $0.564^{a}$ & 0.087 \\
\hline Sig. (two-tailed) & & 0.046 & 0.11 & 0.021 & 0.625 \\
\hline $\begin{array}{l}\text { Small business } \\
\text { support services }\end{array}$ & 0.331 & 1 & 0.062 & 0.141 & 0.294 \\
\hline Sig. (two-tailed) & 0.056 & . & 0.716 & 0.425 & 0.091 \\
\hline $\begin{array}{l}\text { Awareness of funding } \\
\text { opportunities }\end{array}$ & 0.054 & 0.062 & 1 & 0.065 & 0.055 \\
\hline Sig. (two-tailed) & 0.760 & 0.726 & . & 0.716 & 0.756 \\
\hline $\begin{array}{l}\text { Structure of financial } \\
\text { sector }\end{array}$ & $0.564^{\mathrm{a}}$ & 0.141 & 0.065 & 1 & 0.309 \\
\hline Sig. (two-tailed) & 0.001 & 0.425 & 0.716 & . & 0.076 \\
\hline Access to finance & 0.087 & 0.294 & 0.055 & 0.309 & 1 \\
\hline Sig. (two-tailed) & 0.625 & 0.091 & 0.756 & 0.076 & . \\
\hline
\end{tabular}

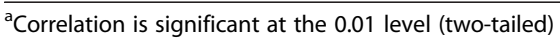


Table 4 Coefficient of determination $\left(R^{2}\right)$

\begin{tabular}{lllll}
\hline Model & $R$ & $R$ square & Adjusted $R$ square & Standard error of the estimate \\
\hline 1 & $0.273^{\text {a }}$ & 0.747 & 0.703 & 0.71611 \\
\hline $\begin{array}{l}\text { apredictors: (constant), collateral requirement, awareness of funding opportunities, structure of financial sector, and small } \\
\text { business support services }\end{array}$
\end{tabular}

small business support services to the dependent variable have a significant contribution to access to finance (Table 6).

\section{Discussion}

This section discusses the findings from the study, and also it draws the conclusions based on the objectives of the study.

\section{Discussion of findings}

Influence of collateral requirements in access to finance

The study sought to establish the influence of collateral requirements on access to finance. Collateral refers to the assets committed by borrowers to a lender as security for debt payment (Gitman, 2003).

The study found that collateral requirements influence access to finance by SMEs in Mozambique. It is evident that most SMEs are denied and discriminated by the lenders in provision of financing. This is because of high risk and for not having adequate resources to provide as collateral. The study also found that houses, land, and businesses are used as security and that banks demand SMEs to post the collateral in order to reduce moral hazard. This finding is in line with the findings of Mullei and Bokea (2000) that banks ask for collaterals in order to finance SMEs and to accept loan proposal and that the collateral must therefore be $100 \%$ or more, equal to the amount of credit extension or finance product.

Further, the study revealed that collateral creates disincentive to the SMEs to acquire bank financing and that SMEs are discriminated by banks due to high risks in lending to them. This finding concurs with Kihimbo et al. (2012) that most SMEs are denied and discriminated by the lenders in providing financing.

\section{Effect of small business support services in access to finance}

The study found that small business support services influence access to finance by SMEs. Charbonneau and Menon (2013) suggest that SMEs for their sustenance need to use ICT which can then make them become more competitive and provide opportunities to participate in global value chains. Small business support services are provided by national agencies, both private and public.

Table 5 ANOVA

\begin{tabular}{lllllll}
\hline Model & & Sum of squares & $\mathrm{df}$ & Mean square & $F$ & Sig. \\
\hline 1 & Regression & 6.227 & 14 & 1.557 & 4.244 & $0.034^{\mathrm{a}}$ \\
& Residual & 18.831 & 432 & 0.649 & & \\
& Total & 25.059 & 446 & & & \\
\hline
\end{tabular}

aPredictors: (constant), collateral requirement, awareness of funding opportunities, structure of financial sector, and small business support services

Dependent variable: access to finance 
Table 6 Regression coefficients

\begin{tabular}{|c|c|c|c|c|c|}
\hline & \multicolumn{2}{|c|}{ Unstandardized coefficients } & \multirow{2}{*}{$\begin{array}{l}\text { Standardized coefficients } \\
\text { Beta }\end{array}$} & \multirow[t]{2}{*}{$t$} & \multirow[t]{2}{*}{ Sig. } \\
\hline & $B$ & Standard error & & & \\
\hline (Constant) & 1.138 & 0.3917 & & 2.905 & 0.000 \\
\hline Collateral requirement & 0.479 & 0.2397 & 0.586 & 1.998 & 0.001 \\
\hline Small business support services & 0.157 & 0.0724 & 0.238 & 2.169 & 0.033 \\
\hline Awareness of funding opportunities & 0.423 & 0.1897 & 0.609 & 2.229 & 0.031 \\
\hline Structure of financial sector & 0.258 & 0.1304 & 0.387 & 1.979 & 0.003 \\
\hline
\end{tabular}

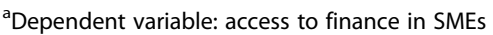

Also the respondents agreed that small business support services could improve access to finance and that there are enough number of funding programs and financial schemes to assist SMEs but most of them are not able make proper proposals for funding. This finding agrees with Rambo (2013) observations that most SMEs are not aware of funding programs and that most SMEs face difficulties in accessing funds to invest in their projects.

\section{Influence of the structure of financial sector in access to finance}

The study showed that that the regulatory regime in Mozambique influences access to finance. This study finding disagrees with the findings of Scott and William (2001) that there is no clear relationship between regulatory restriction, interference of the government on the process of intermediation and banking system's competitiveness and SMEs' access to finance. This study therefore concludes that the regulatory regime should increase the efficiency and competitiveness in the banking system and make access to finance easier.

\section{Effect of awareness of funding opportunities in access to finance}

The study found that awareness of funding affects access to finance. It was found that there is information asymmetry. The financial institutions know very little about the SMEs. Information asymmetries are actually concerned with the two players in the financial market. In this case, the borrowers know more about their business cases and the bankers may not know more about it on one hand. On the other hand, it entails the lack of timely, accurate, quality, quantity, and complete information regarding the ability of the applicants to repay back the loan and to access financial products from the banking institutions.

The study revealed that the banks require more information to evaluate potential risks associated to SMEs. The flow of information in the financial market is crucial for both SMEs and financial providers (Falkena et al., 2001). In order for SMEs to identify potential suppliers of financial services, they require enough information. This study therefore infers that availability of information is essential to both the banks and the SMEs. This will enhance the understanding of the potential risks associated with the SMEs that apply for bank financing and also to access the location where the same SMEs will be operating and its market segments (Othieno, 2010).

\section{Conclusions}

There are a number of observations: SMEs need to use ICT to sustain businesses and to become more competitive and that small business support services could improve access to finance; there is not enough number of funding programs and financial 
schemes to assist SMEs; majority of SMEs are not aware of funding programs and financial schemes provided by the government and private sector; and public and private sectors have not put in place enough funding programs and financial schemes to assist SMEs. In addition, it has been observed that houses, land, and businesses were provided as security and that banks demand SMEs to provide collateral in order to reduce moral hazard; collateral creates disincentive to the SMEs to acquire bank financing and that SMEs are discriminated by banks due to high risks in lending to them. The banking systems and regulatory structure impede access to finance by SMEs. It is further concluded that the banks require more information to evaluate potential risks associated to SMEs in Mozambique. The study concludes that SMEs should be sensitized about funding programs and financial schemes provided by the government and private sector and that public and private sectors put in place funding programs and financial schemes to assist SMEs. The present study was confined to SMEs in Mozambique. For further research, it would be useful to carry out a similar study across East Africa and beyond and see whether the same results would be replicated.

Competing interests

The authors declare that they have no competing interests.

\section{Authors' contributions}

The corresponding author has written the article and co-author has contributed in the collection, analysis and interpretation of the results. Both authors read approved the final manuscript.

\section{Author details}

${ }^{1}$ Africa Nazarene University, P.O. Box 53067 - 00200 Nairobi, Kenya. ${ }^{2}$ Gorongosa Turismo Transportes e Serviços, Lda., Avenida Eduardo Mondlane, no. 1139, Beira City, Mozambique.

Received: 22 December 2015 Accepted: 9 March 2016

Published online: 17 March 2016

\section{References}

ACCA. (2009). Access to finance for small and medium enterprises sector: the evidence and the conclusion.

Agostino, M. (2008). Effects of screening and monitoring on credit rationing of SMEs. Economic notes. 37(2-2008), 155179. Banca Monte dei Paschi di Siena SpA. Oxford: Blackwell Publishing Ltd.

Anzoategui, D., \& Rocha, R. (2010). The competition of banks in the Middle East and Northern Africa region. Washington: Policy Research Working Paper 5363. Washington: World Bank.

Bailey, R. (2000). Research findings. New York: McGraw-Hill.

Bazibu, M. (2005). Information Asymmetry and Borrowers' Performance on Loans in Commercial Banks. Unpublished MBA research dissertation. Kampala: Makerere University.

BBA. (2002). Ethnic minority business in the UK: access to finance and business support. London:British Bankers Association Research Report.

Beck, T. (2007). Financing constraints of SMEs in developing countries: the evidence, determinants and solutions. Retrieved January 2010.

Beck, T., \& Demirguc-Kunt, A. (2006). Small-medium enterprise sector: access to finance as a growth constraint. Journal of Finance and Banking, 30(11), 2931-2943.

Bigsten, A. (2003). Credit constraints in the manufacturing enterprises in Africa. Journal of African Economics, 12(1), $104-125$.

Black, S. E., \& Philip, S. (2002). Entrepreneurship and bank credit availability. Journal of Financd, 57, 2807-2833.

Brownbridge, M. (2002). Banking reforms in Africa: what has been learnt. The New.

Central Bank of Mozambique. (2013). Annual Report, the Bank of Mozambique.

Cetorelli, N., \& Michele, G. (2001). Banking market structure. Financial Dependence and Growth: Int Evidence from Industry Data Journal of Finance, 56, 617-640.

Charbonneau, J., \& Menon, H. (2013). A strategic approach to SME exports growth. The section of Enterprise Competitiveness- ITC. Taipei-Taiwan: Secretariat, Confederation of Asia-Pacific Chambers of Commerce and Industry.

Cole, R. (2003). How did the financial crisis affect small business lending in the US?

Cooper, R., \& Ejarque, J. (2003). Financial friction and investment: requiem in Q review of economic dynamics.

Cooper, C. R., \& Schindler, P. S. (2008). Business research methods (10th ed.). Boston: McGraw-Hill.

Covas, F., \& Den Haan, W. J. (2006). The cyclical behaviour of debt and equity: evidence from a panel of Canadian firms.

Deakins, D. (2008). SMEs' access to finance: is there still a debt finance gap. Belfast: The Institute of Small Business and the Entrepreneurship.

Diagne, A., \& Zeller, M. (2002). The determinant of household access and participation in formal and informal credit market. The Institute of International Food Policy Research, 7(2), 23-31.

DTI. (2010). National Directory of Small Business Support Programs. Pretoria: The DTI.

Easterby-Smith, M., Thorpe, R., \& Jackson, P. R. (1999). The management research: an introduction. London: the Sage Publication Limited. 
Falkena, H., Abedian, I., von Blottnitz, M., Coovadia, C., Davel, G., Madungandaba, J., Masilela, E., \& Rees, S. (2001). SMEs access to finance in South Africa - a supply side regulatory review. Pretoria, South Africa: Policy Board for Financial Services and Regulation.

Fatoki, O. O., \& Smit, A. V. (2011). Constraints to credit access by new SMEs in South Africa: a supply side analysis. The African Journal of Business and Management, 5(4), 1413-1425.

Foltz, J. D. (2004). Credit market access and profitability in Tunisian agriculture. Journal of Agricultural Economics, 130, 229-240.

FSB. (2012). The UK leading business organization. London: Federation of Small Business.

Garrett, J. F. (2009). Bank and their customers. New York: Dobbs Ferry: Oceana Publications.

Gitman, L. J. (2003). The principles of managerial finance (7th ed.). New York: Pearson Education Inc

Gomes, J. F., Yaron, A., \& Zhang, L. (2006). Asset pricing implications of firms financing constraints. Review of the financial studies.

IBGE. (2007). The research of innovation technology_ PINTEC 2005. Rio de Janeiro: The Brazilian institute of geography and statistic.

INE. (2012). The profile of SMEs in Mozambique. Maputo: National Statistics.

IPEME. (2013). Financing SMEs in Mozambique (p. 1,3). Maputo: Know and Use financing SMEs.

Joppe, M. (2000). The research process; Retrieved 25 February 1998, from www.ryerson.ca

Kaufmann, F., \& Wilhelm, P. (2006). The dilemma of small business in Mozambique: a research note, in the developmental entrepreneurship: adversity, risk, and isolation. Amsterdam: Galbraith and Curt Stiles.

Kihimbo, B. W., Ayako, B. A., \& Omoka, K. W. (2012). Collateral requirements for financing of small and medium enterprises (SMES) in Kakamega municipality in Kenya. International Journal of current Research, 4(6), 21-26.

Kothari, C. R. (2004). Research methodology: methods and techniques (2nd ed.). New Delhi: New Age International Publisher.

Leffileur, J. (2009). Financing SMEs in the context of strong information asymmetry. Issue 1, Financing SMEs in Sub Saharan Africa. Private Sector Development. Paris: Proparco.

Mahembe, E. (2011). Literature review on small and medium enterprises' access to finance. Pretoria: National Credit Regulator.

Manasseh, P. N. (2004). A text book of business finance (3rd ed.). Nairobi: McMore Accounting Books.

Matthews, K., \& Thompson, J. (2008). The economics of banking. Chichester: Wiley.

MIC. (2007). Small and medium enterprises in Mozambique situation, perspectives and challenges. Maputo, Mozambique: the Ministry of Trade and Industry.

MIE. (2010). The strategic program of industry development. Maputo, Mozambique: the Ministry of Energy.

MPD. (2007). The development of enterprises in Mozambique: results based on questionnaire in manufacturer sector 2002-2006. Maputo, Mozambique.

Mugenda, A. G. (2008). Social science research: theory and principles. Nairobi: Applied Research and Training Services. Mugenda, M. O., \& Mugenda, A. G. (2003). Research methods: quantitative and qualitative approaches. Nairobi: Acts Press. Mullei, A., \& Bokea, A. (2000). Micro and small enterprises in Kenya: agenda for improving the policy environment. Nairobi: I.C.E.G. Olomi, D., \& Urassa, G. (2008). The constraints to access the capital by SMEs of Tanzania. Dar es Salaam: REPOA.

Othieno, E. A. (2010). Bank lending, information on asymmetry, credit. Kampala: Makerere University.

Rambo, C. M. (2013). Time required to break-even for small and medium enterprises: the Evidence from Kenya. The International Journal of Marketing Research and Management, 6(1), 81-94.

Scott, J., \& William, D. (2001). Competition and credit market outcomes: small firm perspectives. Philadelphia, PA: The Temple University mimeo.

Sekaran, U., \& Bougie, R. (2013). Research methods for business: a skill-building approach (6th Ed). New York: John Wiley \& Sons. Thorsten, B., \& Maksimovic, V. (2003). The competition of the bank and access to finance: international evidence. USAID. (2005). Financial services to support international trade in Mozambique. Maputo: Nathan associates Inc. USAID. (2007). Constraints in financial sector for development of private sector in Mozambique. Maputo: Nathan associates Inc. Watanabe, W. (2005). How are loans by their main bank priced? The bank effects, the information and non price terms of a contract. RIETI Discussion Paper Series 05-E-028.

World Bank. (2003). Pilot investment assessment: Mozambique industrial performance and investment climate. Maputo: CTA/CPI/RPED/APSG/WB

Yitayal, A. M. (2004). Determinants of smallholder farmers access to formal credit: the case of Metema Woreda North Gondar in Ethiopia. Addis Ababa: The World Bank Report.

\section{Submit your manuscript to a SpringerOpen ${ }^{\circ}$} journal and benefit from:

- Convenient online submission

- Rigorous peer review

- Immediate publication on acceptance

- Open access: articles freely available online

- High visibility within the field

- Retaining the copyright to your article

Submit your next manuscript at $>$ springeropen.com 